\title{
Feasibility analysis of smart renewable hubs in non-interconnected island power systems: A case study for gridsol
}

Baldini, Mattia; Bottecchia, Luigi; Riva, Alberto Dalla; Pasquali, Andrea; Estebaranz, Jose Miguel

Published in:

AIP Conference Proceedings

Link to article, DOI:

$10.1063 / 5.0028538$

Publication date:

2020

Document Version

Publisher's PDF, also known as Version of record

Link back to DTU Orbit

Citation (APA):

Baldini, M., Bottecchia, L., Riva, A. D., Pasquali, A., \& Estebaranz, J. M. (2020). Feasibility analysis of smart renewable hubs in non-interconnected island power systems: A case study for gridsol. AIP Conference Proceedings, 2303, [080003]. https://doi.org/10.1063/5.0028538

\section{General rights}

Copyright and moral rights for the publications made accessible in the public portal are retained by the authors and/or other copyright owners and it is a condition of accessing publications that users recognise and abide by the legal requirements associated with these rights.

- Users may download and print one copy of any publication from the public portal for the purpose of private study or research.

- You may not further distribute the material or use it for any profit-making activity or commercial gain

- You may freely distribute the URL identifying the publication in the public portal 


\section{Feasibility analysis of smart renewable hubs in non-interconnected island power systems: A case study for GRIDSOL}

Cite as: AIP Conference Proceedings 2303, 080003 (2020); https://doi.org/10.1063/5.0028538 Published Online: 11 December 2020

Mattia Baldini, Luigi Bottecchia, Alberto Dalla Riva, Andrea Pasquali, and Jose Miguel Estebaranz

\section{ARTICLES YOU MAY BE INTERESTED IN}

\section{Experimental testing of the bladed receiver}

AIP Conference Proceedings 2303, 030030 (2020); https://doi.org/10.1063/5.0029526

Thermodynamic analysis of an indirect supercritical $\mathrm{CO}_{2}$ - air driven concentrated solar power plant with a packed bed thermal energy storage

AIP Conference Proceedings 2303, 130007 (2020); https://doi.org/10.1063/5.0028624

Design process and optimization of helically twisted tapes as a suitable insert for heat transfer enhancement in solar receiver tubes

AIP Conference Proceedings 2303, 070003 (2020); https://doi.org/10.1063/5.0028738

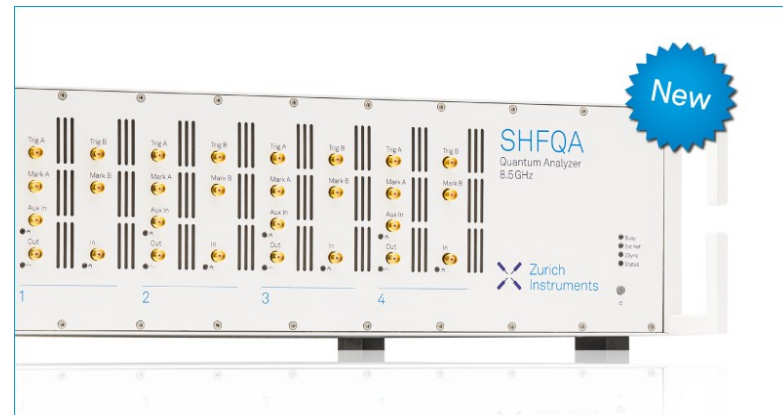

\section{View Online Export citation
0); https://doi.org/10.1063/5.0029526
ical $\mathrm{CO}_{2}$ - air driven concentrated solar power
sted tapes as a suitable insert for heat transfer
0); https://doi.org/10.1063/5.0028738}

Your Qubits. Measured.

Meet the next generation of quantum analyzers

- Readout for up to 64 qubits

- Operation at up to $8.5 \mathrm{GHz}$, mixer-calibration-free

- Signal optimization with minimal latency 


\title{
Feasibility Analysis of Smart Renewable Hubs in Non- Interconnected Island Power Systems: A Case Study for GRIDSOL
}

\author{
Mattia Baldini ${ }^{1, \text { a) }}$, Luigi Bottecchia ${ }^{1}$, Alberto Dalla Riva ${ }^{2, b)}$, Andrea Pasquali ${ }^{2}$, \\ Jose Miguel Estebaranz ${ }^{3, c)}$
}

\author{
${ }^{1}$ Technical University of Denmark, Produktionstorvet, Building 424, 2800, Kgs. Lyngby, Denmark \\ ${ }^{2}$ EA Energy Analyses, Gammel Torv 8, 1457, Copenhagen, Denmark, Denmark \\ ${ }^{3}$ Cobra Industrial Plants \& Energy, C/ Cardenal Marcelo Spinola, 10, 28016, Madrid, Spain
}

\author{
a)Corresponding author: mbal@dtu.dk \\ b) adr@eaea.dk \\ c) jose.estebaranz@grupocobra.com
}

\begin{abstract}
On the path towards the decarbonisation of future energy systems, the GRIDSOL project proposes Smart Renewable Hubs as a solution to provide secure and clean electricity, by combining renewables and storage technologies through an advanced control system. The study aims at evaluating the financial attractiveness of investments in smart renewable hubs according to market framework conditions and local resources, in three non-interconnected systems: Crete, Fuerteventura and Madeira. The cash flow analysis uses three economic indicators (NPV, LCOE and IRR) to investigate investments in the years 2020, 2030 and 2050. The outcomes show that investments in 2030 and 2050 are profitable for almost all the cases and locations. SRH and GRIDSOL configurations perform well in all locations, with SRHs profitability peaking in Fuerteventura (170 [MM€]). The sensitivity analysis performed on LCOEs, which were found to be larger than the average generation prices, shows that changes in PV and CSP CAPEX mostly affect the results. In some cases, changes in biogas, $\mathrm{CO}_{2}$ and natural gas prices are also relevant. Future developments in technology costs and remuneration frameworks will likely pave the way for the competitive case of smart renewable hubs in island energy systems.
\end{abstract}

\section{INTRODUCTION}

The European Union (EU), on the path for the EU 2030 and EU 2050 energy road-maps, is working to decarbonize the energy systems. Solutions have been proposed targeting technologies advancement, energy markets transformation and enhanced schemes of policy support. In this framework, consistent efforts are directed to island cases as, being isolated systems characterized by aged fossil-fuel based technologies and with high electricity prices, they pose major challenges for the transformation of the European energy system.

To this end, the European-funded GRIDSOL project proposes Smart Renewable Hubs (SRHs) designed to provide secure, clean and efficient electricity by combining primary renewable energy sources and storage technologies under an advanced control system, the Dynamic Output Manager of Energy (DOME) [1]. The concept aims at solving the problem at the generation level, linking non-synchronous, non-dispatchable renewable energy (RES) technologies, for instance photovoltaic (PV) and wind turbines, with Concentrated Solar Power (CSP) plants, back-up capacity and advanced control technologies. The goal is to maximize the use of available local resources, providing secure electricity and contributing to grid stability through a dispatchable, firm and fully-flexible hybrid renewable hub.

The GRIDSOL design can facilitate the transition to sustainable island energy systems, from an environmental and a market perspective. First, by increasing the penetration of renewable-based technologies in island grids, GRIDSOL can substitute the aged fossil-fuel based plants, responsible for a large share of $\mathrm{CO}_{2}$ emissions. Second, having the potential to offer security of supply and generation flexibility through a multi-hybridised SRH characterized 
by low generation costs, GRIDSOL could find its competitive case in isolated power systems, where generation prices are often high and where market framework conditions largely support conventional power generation.

The recent declining trends in the technology costs, because of progresses on technology development, have increased the economic competitiveness of the renewables against mature conventional power plants. Examples from worldwide auctions on renewable energy generation, for instance the CSP auctions in the United Arab Emirates [2] or other RE-based auctions [3], confirm advantageous competitive results for renewable-based generation. Yet, varying electricity prices and large investment costs still represent a consistent barrier for investors, particularly for not-yet-established technologies such as CSP or hybrid systems. In this framework, the characteristics of the noninterconnected island power systems, with large energy generation costs, pose advantageous conditions.

This study thus focuses on the commercial attractiveness of investments in smart renewable hubs, according to local energy market conditions and technology costs reduction. The feasibility analysis is performed for selected European islands characterized by high solar irradiation: Crete, Madeira and Fuerteventura. Economic indicators, such as Net Present Value (NPV), Internal Rate of Return (IRR) and Levelised Cost of Energy (LCOE), are used to evaluate the financial performances of investments. The analysis further performs sensitivity on relevant input parameters, to observe variations in financial attractiveness. By providing empirical results on the feasibility of investments in GRIDSOL solutions, the study narrows the knowledge gap on the attractiveness of solar-based Smart Renewable Hubs in non-interconnected island power systems.

The remainder of the paper is structured as follows. Section 2 provides a description of the island cases, focusing on the current energy challenges, the market framework conditions and the support schemes for renewables. Section 3 describes the GRIDSOL design and presents the methodology adopted, while Section 4 reports the case study. Last, Section 5 illustrates and describes the outcomes of the analysis and Section 6 concludes the study.

\section{THE ISLAND CASES}

The analysis of the potential integration of hybrid smart renewable hubs within island energy systems is performed for Crete, Fuerteventura and Madeira. All locations are characterized by a great availability of wind and solar resources. The islands present no wholesale electricity markets, due to isolation conditions and the lack of generators for creating a competitive market. Consequently, there is no system marginal price, but an estimated clearance price of energy, calculated on monthly bases, based on the generation costs of the conventional power units. Furthermore, from a technical point of view, the priority in island energy systems is to cover the demand and guarantee security of supply, rather than provide supply at the least costs, which is often the case for the competitive and interconnected market in the mainland.

\section{Energy Challenges}

The three locations present consistent differences in terms of energy demand, energy production and installed capacity. However, their energy systems face similar challenges: large use of fossil-fuel technologies, high energy generation prices and need for RES support. One of the most important aspect in non-interconnected locations is that the energy systems must ensure security of supply. Consequently, fossil-fuel based generators (often oversized for security reasons) dominates the energy production, while renewables-based plants covers a smaller share. Figure 1 illustrates the development of energy production in the recent years, highlighting the contribution of fossil-fuel (grey) and renewable-based (green) technologies.

Another consequence of the isolation conditions is that generation costs are often higher, compared to the mainland. High cost of fuel transportation, demand variability (e.g. summer peaks) and varying climate conditions are also responsible for high generation costs. For instance, the generation costs for the island of Fuerteventura have been up to $166 \%$ higher on average compared to the mainland, in the past years [7-8]. Similar conditions occur for Madeira and Crete.

The large presence of fossil-fuel based generation and the high generation costs paved the way for the use of renewable energy technologies. In the past years, the three islands have been setting quite ambitious plans in terms of sustainable energy development. For instance, Fuerteventura plans to cover $45 \%$ of its electricity generation through RES by 2025 [9], while Madeira plans to reach $50 \%$ already by 2020 [10]. Despite the ambitions, both locations are far behind the goals, and currently have a $2 \%$ and $15 \%$ share of RES in the electricity generation respectively (See historical share in Figure 1). 


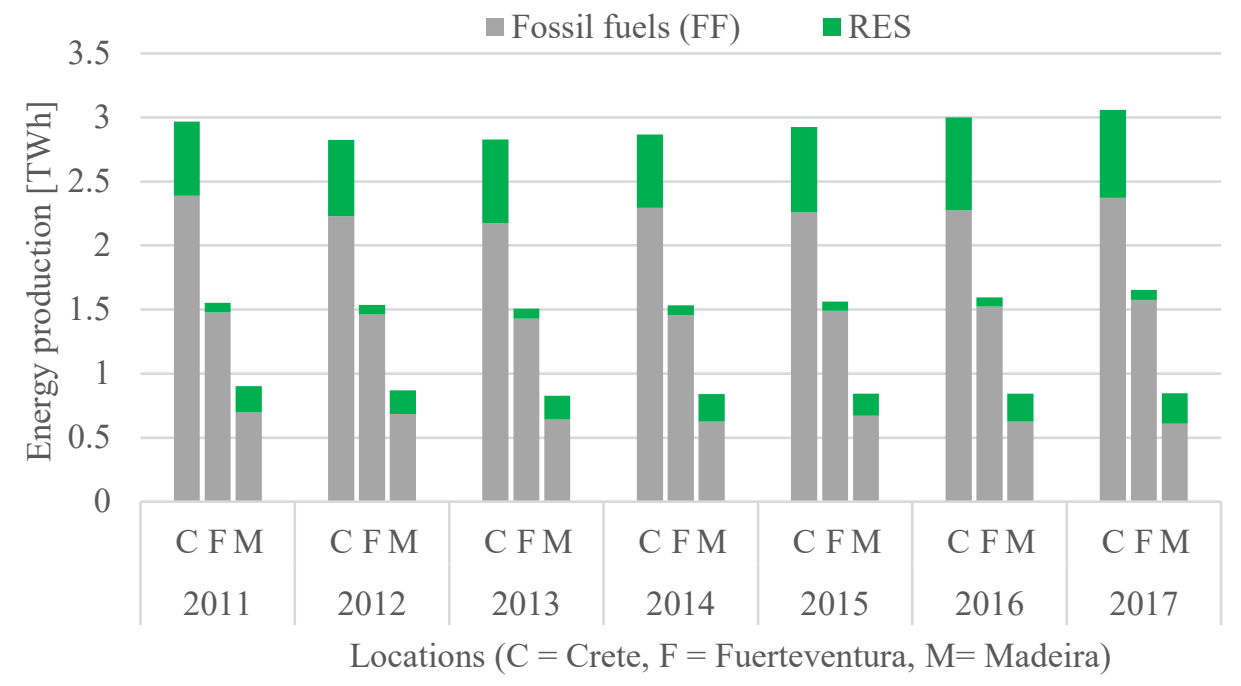

FIGURE 1. Energy production for demand purposes by location and year [TWh] [4-6].

\section{Remuneration Frameworks for Conventional and RES-based Plants}

Although renewable-based technologies represent a valid alternative for generating electricity in the island energy systems, their investments are often hindered by the large investments costs. Policy makers have tried to overcome the challenge by designing special regulations. All the three locations are in fact subject to tailored policies, aiming at reducing the generation costs and easing the investments (e.g. by providing subsidies on capacity). Table 1 provides an overview of the policies currently in place, to regulate the electricity production and RES investments in the island energy systems.

TABLE 1. Remuneration mechanisms for energy production in the three locations [11-14].

\begin{tabular}{|c|c|c|c|c|c|}
\hline Location & Support Type & Plant Type & $\begin{array}{l}\text { Fixed } \\
\text { Costs } \\
{[€ / \mathbf{M W}]}\end{array}$ & $\begin{array}{c}\text { Variable } \\
\text { Costs } \\
{[\in / M W h]}\end{array}$ & $\begin{array}{c}\text { Power } \\
\text { Remuneration } \\
{[€ / M W h]}\end{array}$ \\
\hline Crete & Law 4414/2016 & $\begin{array}{c}\text { RES } \\
\text { Cogneration }\end{array}$ & & $\begin{array}{l}\mathrm{X} \\
\mathrm{X}\end{array}$ & \\
\hline Fuerteventura & $\begin{array}{l}\text { Régimen Retributivo Adicional } \\
\text { Régimen Retributivo Específico }\end{array}$ & $\begin{array}{c}\text { RES } \\
\text { Conventional }\end{array}$ & $\begin{array}{c}\mathrm{R}_{\text {inv }} \\
\mathrm{X}\end{array}$ & $\begin{array}{l}\mathrm{R}_{\mathrm{o}}, \mathrm{I}_{\text {inv }} \\
\mathrm{X}\end{array}$ & $\mathrm{X}$ \\
\hline Madeira & Special Production Regime & $\begin{array}{c}\text { RES } \\
\text { Cogeneration }\end{array}$ & & $\begin{array}{l}X \\
X\end{array}$ & \\
\hline
\end{tabular}

In all the locations considered, the support is available through feed-in tariffs (FIT). In Greece FIT are only available for non-interconnected systems; meaning that once Crete will be connected to the mainland, the support will switch to feed-in premium (FIP). In Fuerteventura, the support is available in different forms, according to two different Real Decretos (RD). The RD 738/2015, establishing the Régimen Retributivo Adicional, regulates the electricity production in non-peninsular territories and defines regulations and remuneration mechanisms for conventional and renewable power plants [12]. The RD 413/2014 elaborates thoroughly on the support mechanisms for renewable-based technologies and aims at covering the high installation costs, eventually allowing RES plants to compete equally with well-established technologies, to obtain a reasonable profit and to reduce the overall system costs. The Decretos guarantee that the high installation costs for RES based projects are reduced, through a capacity based support [€/MW], based on the size and overall availability of the plant during the year. The Decretos also define a support for variable costs $\left(\mathrm{R}_{\mathrm{o}}[€ / \mathrm{MWh}]\right)$ tailored according to the plant type and characteristics and, only for new RES installation, an additional incentive $\mathrm{I}_{\text {inv }}[€ / \mathrm{MWh}]$. Finally, all RES based plants are receiving a power remuneration on top of these incentives (Ph-venta). In Madeira, the remuneration framework is slightly different, and it is based on profits from the sale of electricity at a pre-defined value (i.e. maximum allowed revenues per unit). The 
Regulatory Agency for the Energy Services (Entitade reguladora dos serviços energeticos - ERSE, in Portuguese), responsible for electricity tariffs in the island, compensates the local electricity operator ("Empresa de Electricidade da Madeira - EEM") for the difference between generation costs and electricity tariffs. The difference, defined as "deficit tariff", represents a burden for the Portuguese state. Hence, to minimize the deficit and support electricity generation with lower costs, the Special Production Regime (PRE) has been implemented in Madeira [14].

\section{Relevance of SRHs}

It is in this context of large fossil-fuel generation, high generation prices and support frameworks for renewablebased installations that smart renewable hubs can become attractive solutions for non-interconnected energy systems. By combining different technologies, renewable sources and storage systems, SRHs can contribute to the transformation to more sustainable energy systems. At the same time, they can guarantee security of supply and potentially replace the role of conventional power plants. The storage technologies available increase the flexibility of the hub, adjusting the mismatch between renewable energy production and energy demand, reducing the curtailment.

Regardless of the potential benefits, the SRHs still rely on a mix of technologies, which are at a different stage of maturity. Meaning that investment costs and other external parameters (e.g. power remuneration, gas, biogas and $\mathrm{CO}_{2}$ prices) can affect the profitability of investments, from the point of view of the investor, now and in future years. Based on the specific remuneration frameworks available, and the potential benefits in the local energy systems, this analysis investigates the attractiveness of investments in various smart renewable hubs configurations.

\section{METHODOLOGY}

The study relies on two distinct methodological approaches: the GRIDSOL design and the feasibility analysis. The first refers to the method adopted to:

- identify the optimal size of the technologies according to local conditions,

- analyze their operation in the local energy systems,

- generate consistent inputs for the feasibility analysis (e.g. hourly profiles of energy production from the SRH).

The second refers to the method and the assumptions considered for assessing the commercial attractiveness of investments in GRIDSOL configurations; hence, the definition of the economic indicators. The approaches are interlinked: the outputs from the GRIDSOL design analyses are the inputs for the feasibility analysis. Figure 2 represents graphically the methods and data flow.

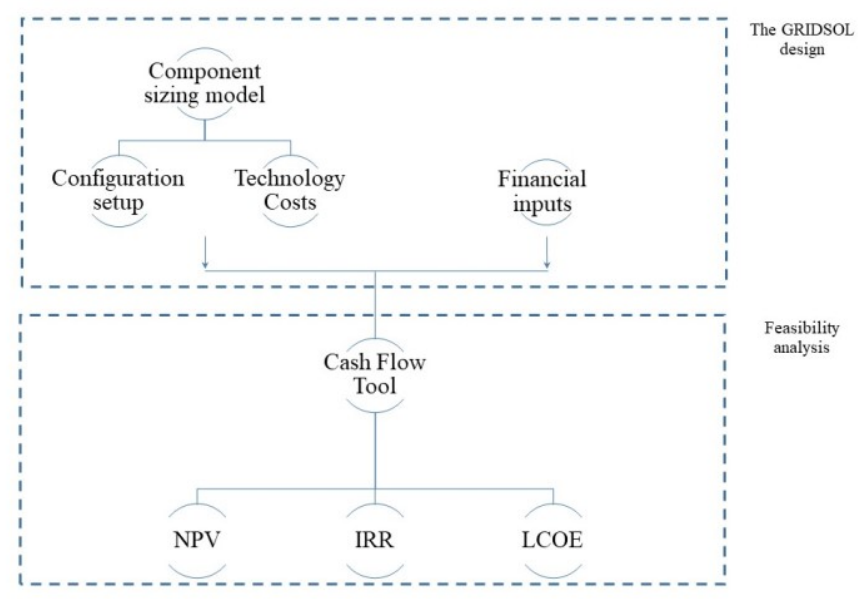

FIGURE 2. Methods and data flow. 


\section{The GRIDSOL Design}

The core idea of the GRIDSOL design is to couple the fluctuating production from renewable-based technologies with thermal and electrical storage systems. Figure 3 illustrates the basic configuration of a GRIDSOL hub, highlighting the interaction among technologies. The CSP plant heats the molten salts through a central tower receiver and stores them in a thermal storage. A gas-based turbine produces electricity and heat which, through a heat-recovery system, is also funneled to the thermal storage. The hot molten salts from the storage evaporate water and generate steam, which is used in a steam turbine to generate electricity. Additional renewable based plants, such as PV and wind turbines, contributes to generate electricity. Battery energy storage systems (BESS) are also available, to store and release electricity according to convenience. The dynamic output manager of energy (DOME) manages the operation of the technologies, and acts as an interface between the hub and the local energy system.

The base configuration of GRIDSOL can be subject to variations in terms of technologies considered and capacity, according to elements such as availability of renewable energy sources, orthography of the landscape and support conditions, which can differ for each of the cases considered. Analyses performed by project partners determine optimal configurations of GRIDSOL technologies according to the island conditions and specifics (e.g. solar irradiation availability) [15]. The same analyses are based on energy systems optimization tools (Component sizing model), which also investigate GRIDSOL's resilience and adaptability within the island energy system considered. This study investigates three potential configurations, obtained with different optimization criteria:

1. BioGRIDSOL: a system including a biogas turbine, with a CSP plant forced into the mix;

2. GRIDSOL: a system including a natural gas turbine, with a CSP plant forced into the mix;

3. SRH: a system with no specific technology forced into the mix, but with at least two generators and one storage system available.

The optimization of the hub, performed through the tailored-made tool "Smart Renewable Hub Modeler", mirrors the decision-making process of a plant operator, which aims at a control strategy based on four key targets: maximization of renewable content, minimization of curtailment, firmness of the plant and optimization of the financial performances. The optimization considers the hub as a whole, rather each technology separately. Starting from a "seed" configuration, the model tests an array of hubs varying the installed capacity of each technology and analyzing the related energy production. The optimization process considers both technical (e.g. start up, profiles of renewable generation) and environmental criteria (e.g. use of land) and provides, according to the optimization criteria, a GRIDSOL configuration with technologies of different capacity and type. For a full description of the objective function and related mathematical formulations, the inputs and the model assumptions, the reader can refer to [15].

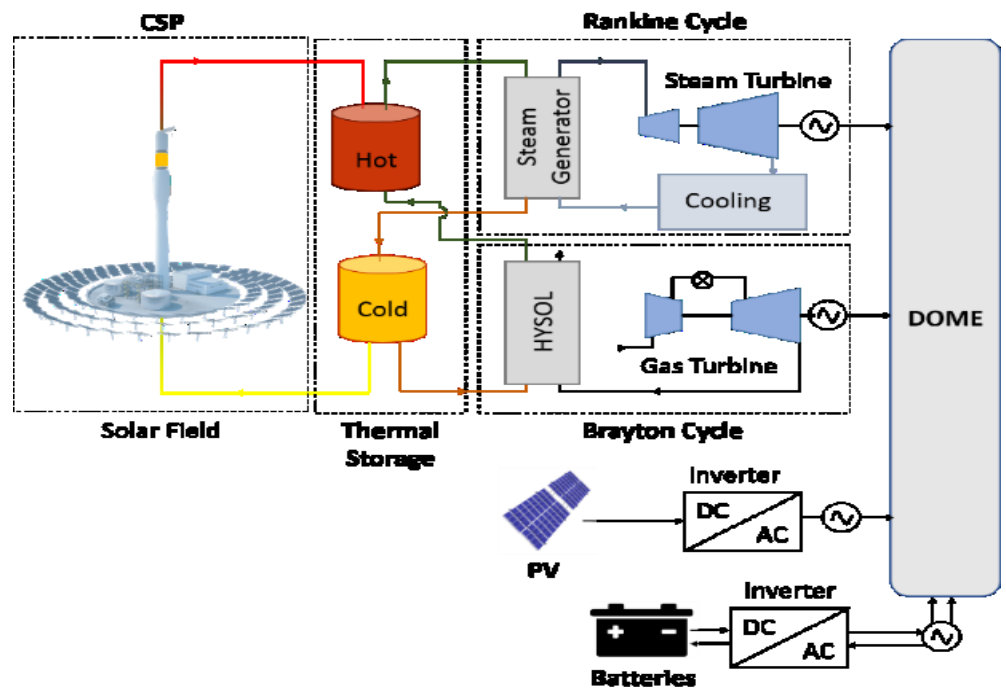

FIGURE 3. GRIDSOL base configuration. 


\section{Cash Flow Analysis}

On the bases of the configurations reported and the different technologies involved, this study performs a feasibility study, through a customized cash-flow tool, to analyze the attractiveness of investment for different years. Three economic indicators evaluate the project feasibility: the Net Present Value (NPV), the Levelised Cost of Energy (LCOE) and the Internal Rate of Return (IRR). The NPV of investing in a GRIDSOL configuration is calculated according to Eq.1, where $C F_{0}$ is the initial investment at the year $\mathrm{t}=0, C F_{t}$ is the free cash flow for each year during the lifetime $(t=1, \ldots, T)$ and discounted by the discount factor $\frac{1}{(1+r)^{t}}$, to consider the time value of revenues $(r$ is the discount rate).

$$
N P V=-C F_{0}+\sum_{t=1}^{T} \frac{C F_{t}}{(1+r)^{t}}
$$

The LCOE is the ratio between the discounted NPV of the negative cash flows (e.g. OPEX, CAPEX, taxes, etc...) and the total discounted energy production. In Eq.2, $N C_{t}$ is the negative cash flow for each year $t$ and $E_{t}$ is the total electricity produced in each year $t$.

$$
L C O E=\frac{\sum_{t=1}^{T} \frac{N C_{t}}{(1+r)^{t}}}{\sum_{t=1}^{T} \frac{E_{t}}{(1+r)^{t}}}
$$

The third economic indicator is the IRR, which is the annual return that a project is expected to yield. It represents the discount rate at which the NPV is equal to 0, as reported in Eq.3.

$$
0=-C F_{0}+\sum_{t=1}^{T} \frac{C F_{t}}{(1+r)^{t}}
$$

The project is assessed feasible (i.e. economically attractive o profitable) if the net present value of investment, considering expenses and revenues during the lifetime, is positive (i.e. NPV $>0$ ) and/or if the internal rate of return is larger than the discount rate (i.e. IRR $>$ r). The LCOE is used to compare the cost of electricity production with the other technologies in the energy system under study. An LCOE lower than the average local generation costs can already suggest an attractive technology for generation purposes. In addition, the LCOE is useful to assess the level of remuneration, necessary to become competitive according to the local energy systems conditions.

\section{CASE STUDY}

Based on the methods presented, the section illustrates data and assumptions for the feasibility analysis. The technical data are the outcomes of the analysis performed by project partners (See Fig.2) [15], while the financial data have been collected from the remuneration frameworks available in the three island locations considered. The analysis is performed for different investment years, respectively: 2020, 2030 and 2050.

\section{Technical Data}

Table 2 presents the technical data for the cash-flow analysis, according to location, configuration, and technology. The values show that capacities and electricity production differ among locations and configurations; this is a direct result of the optimal sizing process performed and of the various local conditions (e.g. wind and solar resources). For instance, the PV technology is predominant in Crete and the largest installed wind capacity is in Fuerteventura. Among the cases, Madeira displays lower capacity installed and lower energy production, in line with the levels of electricity demands in the islands (See Fig.1).

TABLE 2. Installed capacity [MW] and annual electricity production [GWh] by locations and configuration. Configuration $1=$ BioGRIDSOL, $2=$ GRIDSOL and $3=$ SRH [15].

\begin{tabular}{ccccccccccc}
\hline \multirow{2}{*}{ Location } & \multirow{2}{*}{ Conf. } & Data & Wind & PV & $\begin{array}{c}\text { BEES- } \\
\text { MW }\end{array}$ & $\begin{array}{c}\text { BEES- } \\
\text { MWh }\end{array}$ & GT & $\begin{array}{c}\text { CSP- } \\
\text { Receiver }\end{array}$ & $\begin{array}{c}\text { CSP-TES } \\
{[\text { [MWht] }}\end{array}$ & $\begin{array}{c}\text { CSP- } \\
\text { ST }\end{array}$ \\
\hline \multirow{4}{*}{ Crete } & 1 & $\begin{array}{c}\text { Capacity } \\
\text { Production }\end{array}$ & 14 & 34 & 4 & 12 & 8 & 40 & 437 & 16 \\
& \multirow{2}{*}{2} & Capacity & 8 & 45 & 3 & & 17 & & & 32 \\
\cline { 2 - 10 } & & Production & 9 & 51 & 5 & & 5 & 37 & 708 & 15 \\
\hline
\end{tabular}




\begin{tabular}{|c|c|c|c|c|c|c|c|c|c|c|}
\hline Location & Conf. & Data & Wind & PV & $\begin{array}{l}\text { BEES- } \\
\text { MW }\end{array}$ & $\begin{array}{l}\text { BEES- } \\
\text { MWh }\end{array}$ & GT & $\begin{array}{c}\text { CSP- } \\
\text { Receiver }\end{array}$ & $\begin{array}{c}\text { CSP-TES } \\
{[\mathrm{MWh}]}\end{array}$ & $\begin{array}{c}\text { CSP- } \\
\text { ST }\end{array}$ \\
\hline \multirow{2}{*}{ Crete } & \multirow{2}{*}{3} & Capacity & 10 & 41 & 5 & 20 & 5 & 37 & 708 & 15 \\
\hline & & Production & 11 & 51 & 4 & & 10 & & & 37 \\
\hline \multirow{6}{*}{$\begin{array}{l}\text { Fuerte- } \\
\text { ventura }\end{array}$} & \multirow{2}{*}{1} & Capacity & 24 & 23 & 3 & 9 & 15 & 27 & 219 & 11 \\
\hline & & Production & 66 & 44 & 2 & & 75 & & & 51 \\
\hline & \multirow{2}{*}{2} & Capacity & 12 & 15 & 3 & 9 & 5 & 30 & 582 & 12 \\
\hline & & Production & 27 & 28 & 2 & & 9 & & & 52 \\
\hline & \multirow{2}{*}{3} & Capacity & 12 & 11 & 1 & 2 & & 45 & 894 & 18 \\
\hline & & Production & 27 & 21 & 400 & & & & & 66 \\
\hline \multirow{6}{*}{ Madeira } & \multirow{2}{*}{1} & Capacity & 6 & 16 & 1 & 4 & 5 & 5 & 74 & 2 \\
\hline & & Production & 6 & 19 & 12 & & 21 & & & 12 \\
\hline & \multirow{2}{*}{2} & Capacity & 10 & 28 & 9 & 45 & 4 & 7 & 149 & 3 \\
\hline & & Production & 8 & 22 & 11 & & 8 & & & 11 \\
\hline & \multirow[b]{2}{*}{3} & Capacity & 10 & 30 & 9 & 54 & 4 & 5 & 94 & 2 \\
\hline & & Production & 78 & 23 & 13 & & 8 & & & 8 \\
\hline
\end{tabular}

The analysis assumes different levels of capital (CAPEX) and operational (OPEX) expenditures, according to each technology and investment year. Table 3 provides an overview of the CAPEX $(\mathrm{M} €=* 1000 €)$.

TABLE 3. Estimated investment costs (CAPEX) per technology and year of investment [16-18].

\begin{tabular}{cccccc}
\hline Technology & Component & Unit & $\mathbf{2 0 2 0}$ & $\mathbf{2 0 3 0}$ & $\mathbf{2 0 5 0}$ \\
\hline \multirow{2}{*}{ CSP } & Receiver & M€/MWth & 372 & 317 & 276 \\
& TES & M€/MWh-th & 20 & 15.5 & 12.3 \\
& Power Block (ST) & M€/MWe & 1425 & 1245 & 1112 \\
\hline \multirow{2}{*}{ Wind } & & M€/MW & 940 & 860 & 790 \\
\hline PV & & M€/MW & 617 & 510 & 413 \\
\hline \multirow{2}{*}{ BEES } & Power Installed & M€/MW & 150 & 50 & 25 \\
& Capacity & M€/MWh & 300 & 120 & 65 \\
\hline GT+HYSOL & & M€/MW & 652 & 625 & 592 \\
\hline
\end{tabular}

Table 4 shows the variable and fixed OPEX costs. Throughout the study, both CAPEX and OPEX were assumed to be the same for all the three locations. The assumption is non-trivial, as potentially there are other local factors relevant to consider (such as weather particularities), which could impact the design of the components of the CSP plant and, consequently, the CAPEX and OPEX for each location. Nonetheless, due to the long-term horizon considered for the analyses (and the related difficulties to estimate location-tailored values in different years) and to be aligned with the work performed by other researchers in the same project, the authors considered the same CAPEX and OPEX for each location, estimating the costs based on discussions with relevant stakeholder in the field.

Additional assumptions, useful for the cash-flow analysis, include the technical lifetime (25 years) [17], the degradation of performances/production (0.4\%/year, a part for $0.5 \%$ /year for the PV)[18], the overhaul period (7 years)[17] and the increase of O\&M during overhaul (7\%) [17].

TABLE 4. Estimated operational Costs (OPEX) per technology and year of investment [16-18].

\begin{tabular}{|c|c|c|c|c|c|c|}
\hline OPEX & Technology & Component & Unit & 2020 & 2030 & 2050 \\
\hline \multirow{3}{*}{ Variable } & CSP & & $€ / \mathrm{MWh}$ & 0.07 & 0.07 & 0.07 \\
\hline & Wind & & $€ / M W h$ & 2.5 & 2.3 & 2.1 \\
\hline & GT+HYSOL & & $€ / M W h$ & 4.5 & 4.5 & 4.5 \\
\hline \multirow{7}{*}{ Fixed } & \multirow{3}{*}{ CSP } & Receiver & M€/MWth/year & 15.9 & 13.3 & 10.12 \\
\hline & & TES & $\mathrm{M} € / \mathrm{MWh}$-th/year & 0.2 & 0.15 & 0.12 \\
\hline & & Power Block (TS) & M€/MWe/year & 14.2 & 12.4 & 11.1 \\
\hline & Wind & & $\mathrm{M} € / \mathrm{MW} /$ year & 23.9 & 22.3 & 21.2 \\
\hline & PV & & $\mathrm{M} € / \mathrm{MW} / \mathrm{year}$ & 8.1 & 6.5 & 5.5 \\
\hline & BEES & & $\mathrm{M} € / \mathrm{MWh}$ inst./year & 7 & 4 & 1 \\
\hline & GT+HYSOL & & M€/MW/year & 23.5 & 23.1 & 22.6 \\
\hline
\end{tabular}




\section{Financial Data}

In regards to the financial inputs, the study separates the values by location, to consider the differences among remuneration frameworks available. As in 2020, the first year of the feasibility study, Crete will be interconnected with the mainland, we consider the average marginal system price for power remuneration rather than the average generation costs of the islands (53.6 [€/MWh] in 2018) [19]. For Fuerteventura, we consider the average Ph-venta, that is the most recent "market-value" of energy production, introduced as new energy framework in the Canary Islands from 2016 (48.07 [€/MWh]) [7]. For the case of Madeira, we consider the maximum allowed revenues per unit of production according to the PRE (57.4 [€/MWh]) [20]. Due to the lack of knowledge on the future price levels, we project the values in 2020, 2030 and 2050 considering the price trends from the past years in each location. Hence for 2020, for Crete we consider an $11 \%$, for Fuerteventura a $25 \%$ and for Madeira a $1 \%$ increase compared to the average values. For 2030 and 2050, due to the long-term horizon, we assume a homogeneous increase of $5 \%$ and $20 \%$ with respect to 2020 and 2030 prices in each location. Although the assumptions might look non-conservative, for example considering that future mainland power prices could increase up to $70 \%$ with respect to 2020 , the authors believe that island energy systems will be affected differently and the price increase will be lower. Table 5 summarizes the assumptions.

TABLE 5. Remuneration price projection [€/MWh].

\begin{tabular}{cccc}
\hline Location & $\mathbf{2 0 2 0}$ & $\mathbf{2 0 3 0}$ & $\mathbf{2 0 5 0}$ \\
\hline Crete & 59.50 & 62.47 & 75.96 \\
Fuerteventura & 60.09 & 63.09 & 75.71 \\
Madeira & 57.97 & 60.87 & 73.04 \\
\hline
\end{tabular}

The price evolution for $\mathrm{CO}_{2}$ is based on the $1.5^{\circ} \mathrm{C}$ scenario by the European Commission [21]: the baseline price for 2020 is 20.91 [ $€ /$ ton], while the final price in 2050 is expected to be 366 [€/ton] (€2018). The assumptions for natural gas prices are based on other partners considerations [22] and range from $341[€ / t]$ in 2020 to 424 [€/t] in 2050 $(€ 2018)$. For the biogas price, the assumption is that the price will be linked to both natural gas and $\mathrm{CO}_{2}$ price, considering a price cap according to future costs in methanisation processes. Accordingly, the value for 2020 is 408 $[€ / t]$, while for 2050 it is assumed to be $924[€ / t](€ / 2018)[22]$.

In terms of RES remuneration, Table 6 summarizes the assumptions according to the existing remuneration frameworks. Note that Fuerteventura also has a capacity support, equal to 0.11 [MM€/MW] for Wind, 0.48 [MM€/MW] for PV, 0.04 (gas) - 0.06 (biogas) [MM€/MW] for HYSOL and 0.53 [MM€/MW] for CSP plants.

TABLE 6. RES remuneration by location and technology [€/MWh].

\begin{tabular}{|c|c|c|c|c|c|}
\hline Location & WIND & PV & BEES & GT HYSOL & CSP \\
\hline Crete & 98 & 90 & 148 & $\begin{array}{c}85 \text { (gas) } \\
204 \text { (biogas) }\end{array}$ & 278 \\
\hline Fuerteventura & 6 & 28 & & $\begin{array}{c}48 \text { (gas) } \\
11 \text { (biogas) }\end{array}$ & 52 \\
\hline Madeira & 71 & 138 & & $\begin{array}{c}86 \text { (gas) } \\
116 \text { (biogas) }\end{array}$ & 270 \\
\hline
\end{tabular}

The cash flow analysis considers a nominal discount rate of $7.5 \%$ for Fuerteventura, $11.4 \%$ for Crete and $7 \%$ for Madeira [23]. Inflation data are consistent with the forecasts from the International Monetary Fund [24]; from 2025, the assumption for inflation is $2 \% /$ fixed per year. The corporate tax rates assumed are $29 \%$ for Crete [25], $4 \%$ for Fuerteventura [26] and 5\% for Madeira [27]. In case of negative cash flows, no taxes are considered.

\section{RESULTS AND DISCUSSION}

\section{Economic Indicators}

Figure 4 and Fig.5 report the results in terms of NPV, IRR and LCOE. Starting with Fig.4, the feasibility analysis shows that investments in 2030 and 2050 are attractive (i.e. NPV>0) in almost all the cases. Only the BioGRIDSOL 
configuration does not reach break-even in Fuerteventura. This is due to the price and use of biogas. The BioGRIDSOL configuration covers more than $30 \%$ of its production using the biogas-based turbine. Considering the future assumptions on the development of the biogas prices, and its high levels, it results clear why such configuration is not profitable. SRH and GRIDSOL configurations perform well in all locations, with SRHs profitability peaking in Fuerteventura (170 MM $€$ ). Overall, the profitability of investments increases in future years, mainly due to the expected decrease in CAPEX and OPEX and the probable increase in the power remuneration.

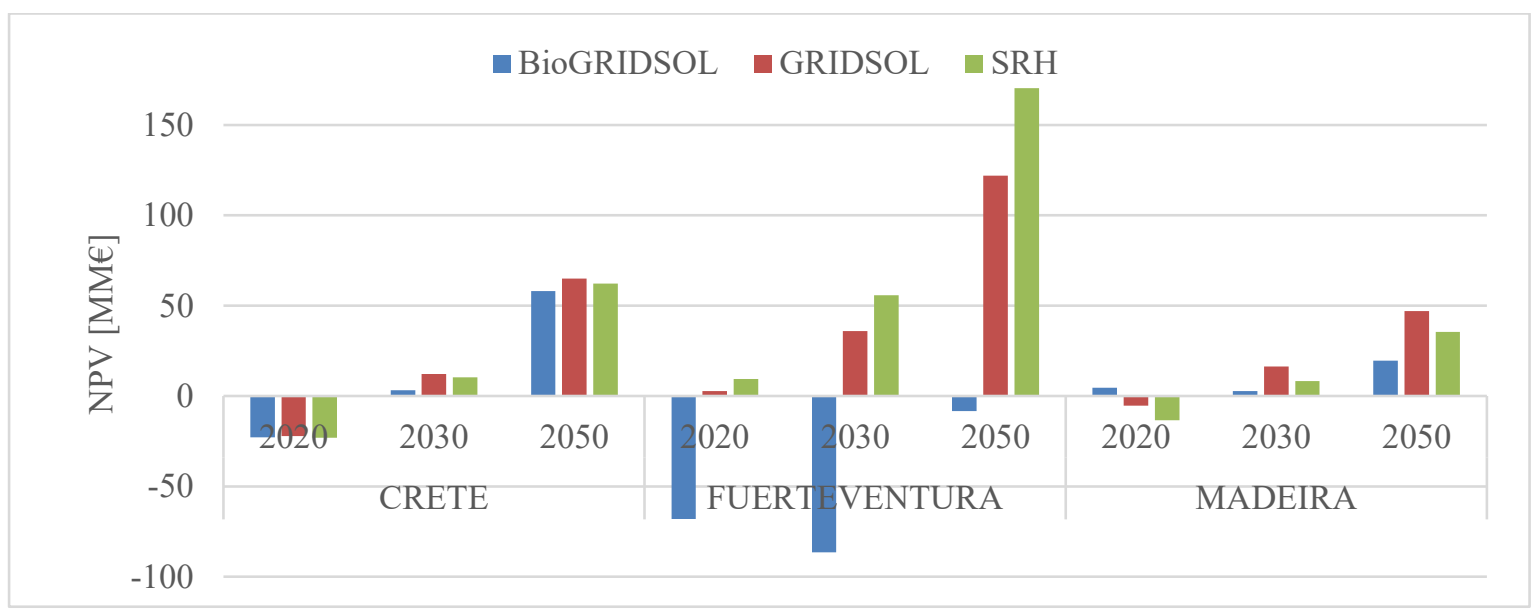

FIGURE 4. Net present value for the configurations analyzed $\left[M M €=10^{6} €\right]$.

Figure 5 reports the results for the other economic indicators, observing the differences between the IRR and the local discount rates in Fig.5 (a) and comparing the LCOE with the average local generation prices in Fig.5 (b). The IRRs in Fig.5 (a) mirror the NPV outcomes in Fig.4: when the NPV $>0$, the IRR is larger than the discount rate (DR); and vice versa. Thus, based on the assumptions, the investments in 2020 for Crete, the BioGRIDSOL configuration in Fuerteventura and the BioGRIDSOL-SRH configurations in Madeira are all non-profitable investments.

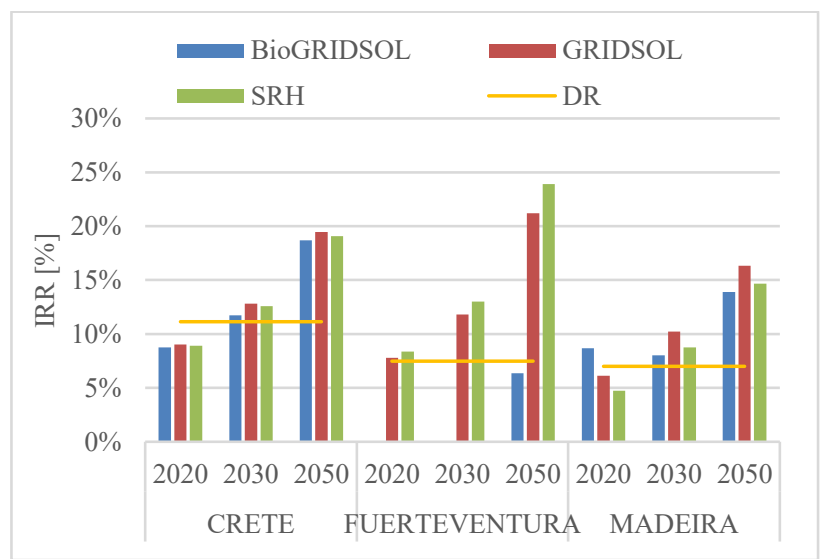

(a) IRR [\%]

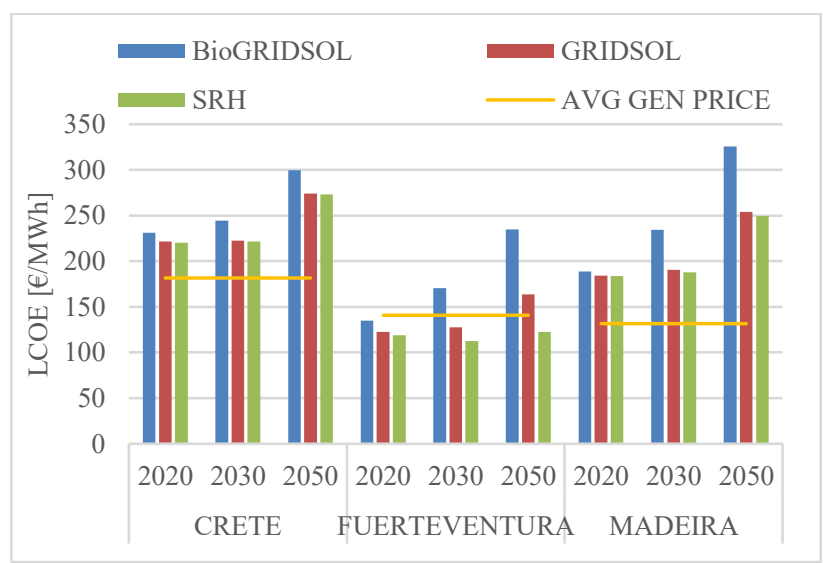

(b) LCOE $[€ / \mathrm{MWh}]$

FIGURE 5. Levelised cost of energy [€/MWh] and internal rate of return [\%] for the configurations analyzed $(\mathrm{DR}=$ discount rate; AVG GEN PRICE = local average generation price).

The opposite is true for all the other configurations. Figure 5 (b) shows that the long-term cost of energy production is higher than the local average generation prices (orange horizontal line), a part for Fuerteventura in 2020 and 2030 (and for SRH in 2050). The outcomes thus highlight that although some configurations are economically attractive from the point of view of the investors, they are not in terms of cost of energy production. The result clash with one of the original objective of the GRIDSOL project, which is to lower the generation costs in the island. Hence, we 
perform a sensitivity analysis, to assess which cost parameters affect the most the competitiveness of investments in various configurations and how cost reduction can boost the attractiveness in terms of energy generation costs.

\section{Sensitivity Analysis}

The sensitivity analysis is performed for the year 2030, as it is not too far in the future (meaning that it is an acceptable future horizon for which variations in the assumptions can occur), but it is far enough to expect progresses in technology development and, consequently, cost reduction. The total operational expenditures of the various configurations suggest that the largest share of the costs is related to capital investments (CAPEX), fuel (gas and biogas) and $\mathrm{CO}_{2}$ costs. Hence, we perform a sensitivity on these parameters, varying the input values and observing the changes in the NPV and LCOE.

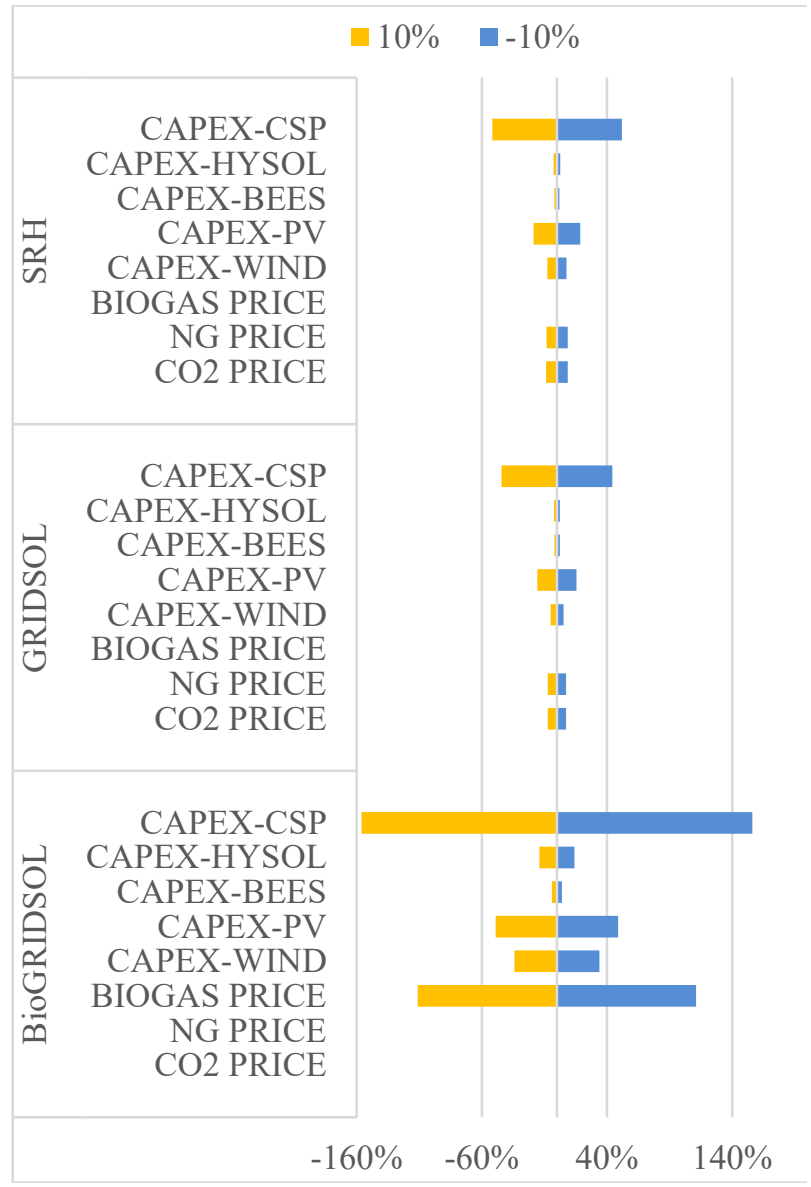

(a) NPV [\%]

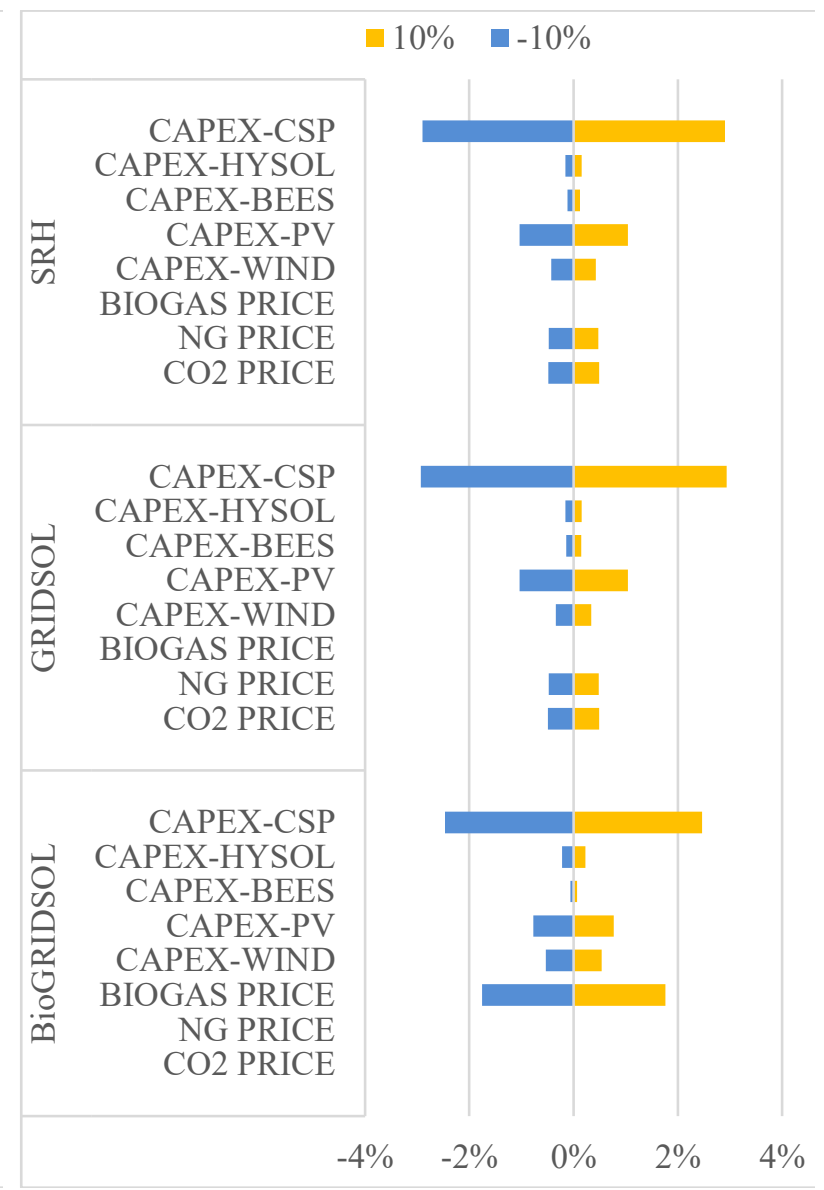

(b) LCOE [\%]

FIGURE 6. Sensitivity analysis on NPV [MM€] and LCOE [€/MWh], Crete.

Figure 6 shows the outcomes for the sensitivity performed on the configurations in Crete. Figure 6 (a) highlights that the NPV is most sensitive to variations in the CSP and PV CAPEX, for all configurations. For instance, for a $10 \%$ decrease in the value of the CSP CAPEX, the NPV increases by $52 \%$ for the SRH, by $44 \%$ for the GRIDSOL and by $156 \%$ for the BioGRIDSOL configuration. The last configuration presents the largest impact compared to the others, due to the larger capacity installed for the steam turbine (which, according to the input data proposed, has the highest investment costs). In addition, the BioGRIDSOL configuration results to be heavily impacted by changes in the biogas price. The same is not valid for the SRH and GRIDSOL configurations, as they are based on natural-gas turbines. Figure 6 (b), presenting the sensitivity for the LCOE, shows similar outcomes, although on a smaller scale. A variation in the CSP and PV CAPEX leads to the largest changes in the LCOEs, with peaks of $2.9 \%$ changes for the SRH and GRIDSOL configuration. Variations in the other CAPEX does not seem to influence heavily the results. 


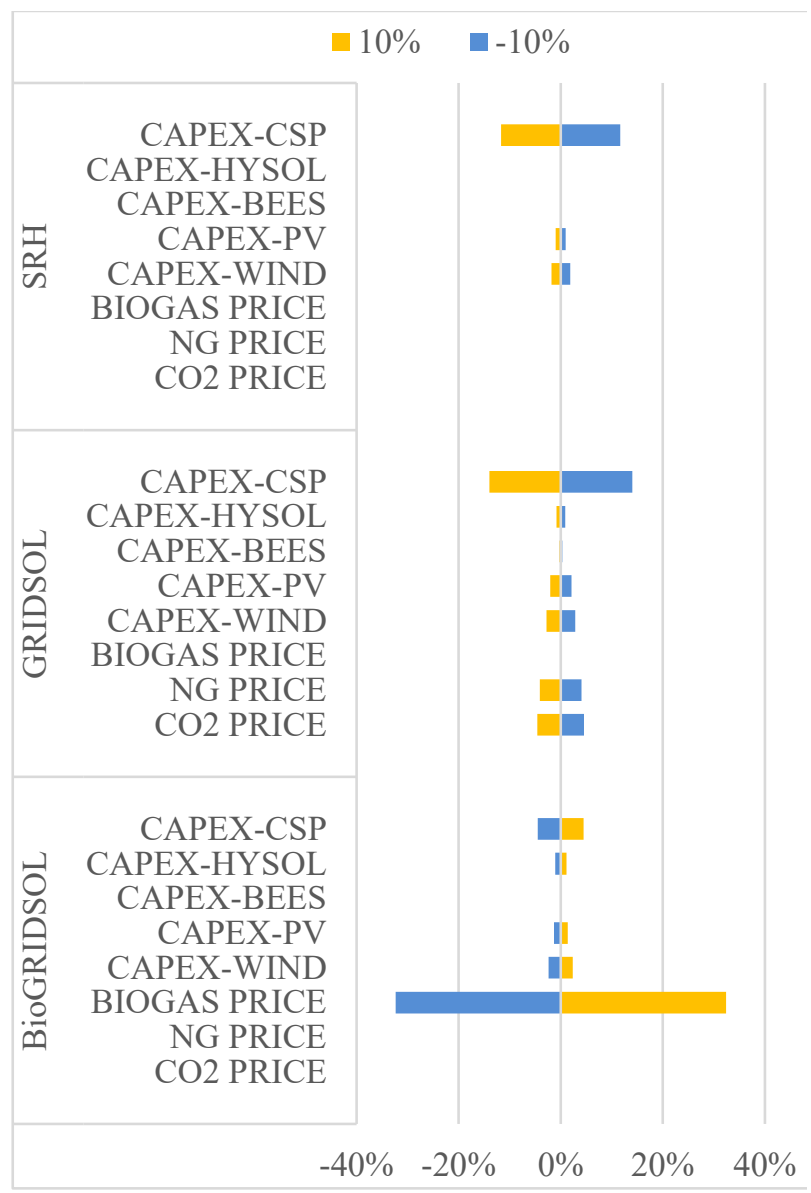

(a) NPV [\%]

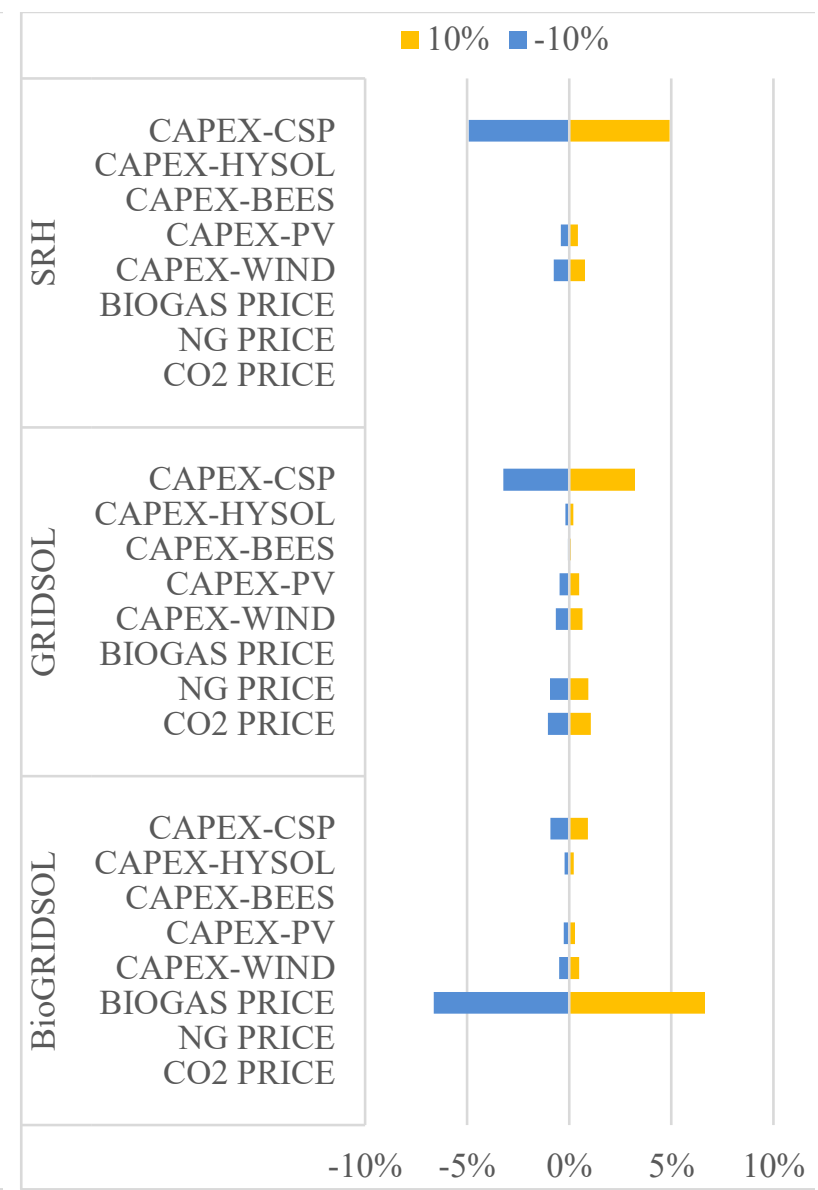

(b) LCOE [\%]

FIGURE 7. Sensitivity analysis on NPV [MM€] and LCOE [€/MWh], Fuerteventura.

The analysis for Fuerteventura shows different outcomes. Figure 7 (a) displays that the NPV is impacted differently, for the same $10 \%$ change in the input parameters. For instance, changes in the CSP CAPEX seem to dominate the variations in NPV for SRH and GRIDSOL configurations, but they do not influence heavily the BioGRIDSOL, where changes in biogas prices affect more the results. Furthermore, variations in the wind CAPEX have the second largest impact on the results for SRH and GRIDSOL, due to the larger support available for PV CAPEX in the Canary Islands (average of 0.48 [MM€/MW] for PV vs. 0.11 [MM€/MW] for wind). Figure 7 (b), showing the variations in LCOEs, reveals similar outcomes. Noticeable are the $6.6 \%$ variation in the BioGRIDSOL due to changes in biogas price and the $4.9 \%$ change due to increase/decrease in the CSP CAPEX for the SRH.

Last, Fig. 8 shows the results for Madeira. For this case, the influence of the input parameters on the NPV is distributed more homogeneously. For the SRH and GRIDSOL configurations, changes in the $\mathrm{CO}_{2}$ and natural gas price have a larger impact compared to other parameters, followed by changes in PV and CSP CAPEX. In the BioGRIDSOL, changes in the biogas price totally dominates (288\%) compared to others (e.g. CSP CAPEX at 29\%). The same can be observed for the sensitivity on the LCOEs. Figure 8 (b) shows that the values are mostly influenced by changes in $\mathrm{CO}_{2}(1.2 \%)$ and natural gas prices $(1.1 \%)$, as well as by changes in PV $(1.1 \%)$ and CSP $(0.6 \%$ average) CAPEX. For the BioGRIDSOL, the variation due to different biogas prices reaches up to $5.2 \%$. Overall, all the configurations in the different locations are largely affected by changes in the CSP-PV CAPEX and biogas prices, although exceptions occur (e.g. $\mathrm{CO}_{2}$ and natural gas prices in Madeira or wind CAPEX in Fuerteventura). In addition to the considerations provided for the sensitivity analysis, one should also note that most of the differences among the island cases are also due to elements such as capacity of the components in the hubs, discount rates or inflation, which are different and tailored to each location. 


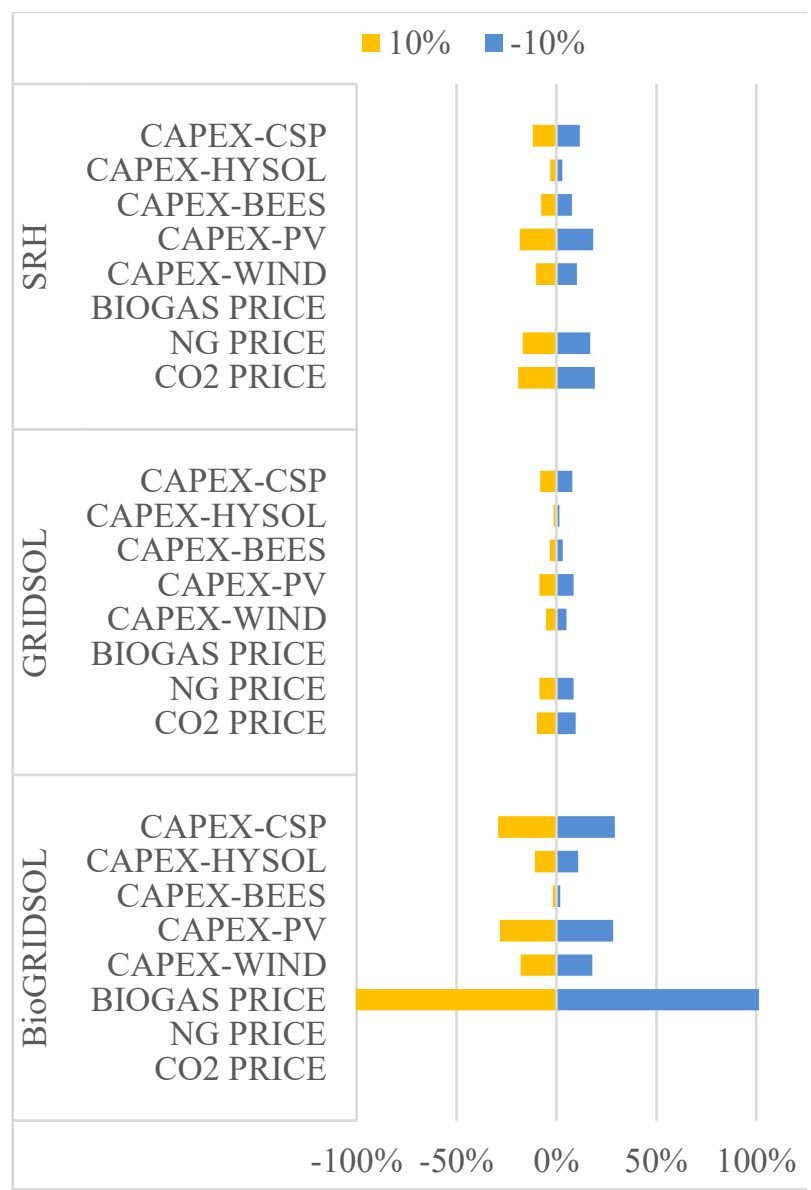

(a) NPV [\%] $(*$ the biogas variation in BioGRIDSOL extends to $288 \%$ and is adjusted for visualization)

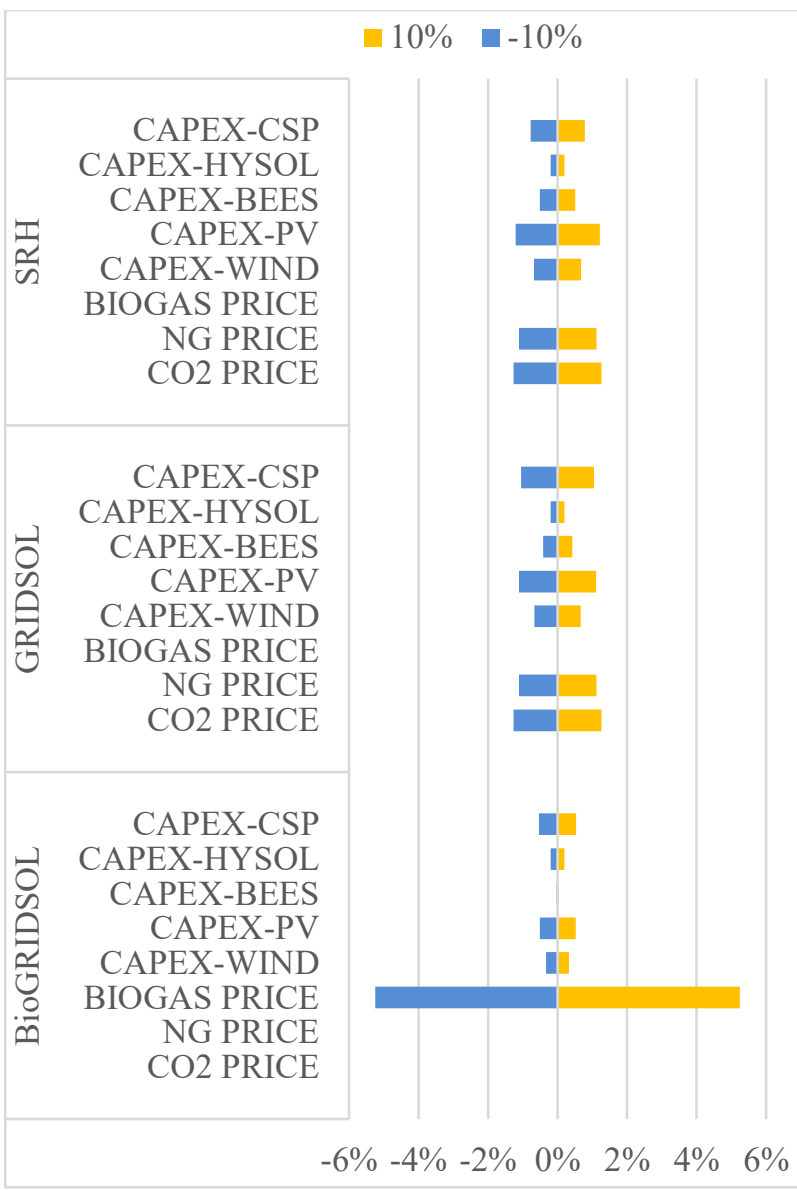

(b) LCOE [\%]

FIGURE 8. Sensitivity analysis on NPV [MM€] and LCOE [€/MWh], Madeira.

\section{CONCLUSIONS}

The paper develops a feasibility study to investigate the commercial attractiveness of investing in smart renewable hubs, in island energy systems. The study considers different hub configurations for each location, according to local resources and conditions. Based on listed assumptions, the economic indicators NPV and IRR suggest profitable investments in 2030 and 2050 for almost all configurations and locations. An exception occurs for BioGRIDSOL in Fuerteventura, where the intensive use of biogas (and its high price) decrease the attractiveness. The values of most LCOEs are found to be still larger than the average generation prices in the islands. The sensitivity analysis performed reveals that potential declines in the CSP and PV CAPEX can increase the competitivity of GRIDSOL solutions. Changes in $\mathrm{CO}_{2}$, gas and biogas prices will also influence the case, differently for each configuration in each location. Furthermore, the expected increase in the $\mathrm{CO}_{2}$ price will likely increase the average generation costs in the island systems, thus making SRH more profitable. The results highlight that, to make GRIDSOL solutions more competitive, there should be a larger focus on $\mathrm{R} \& \mathrm{D}$, technology development and cost reduction throughout the all value chain. A further deployment of technologies like CSP will be also a key to increase the know-how, stimulate efficiency and development. Policy makers should thus foster technology development and tailored remuneration frameworks, aiming at reducing investment costs. In this way, smart renewable hubs will become attractive both economically and in terms of generation costs, promoting the role of renewable-based solutions in island energy systems. 


\section{ACKNOWLEDGMENTS}

The project has received funding from the European Union's Horizon 2020 research and innovation programme under grant agreement No 727362. The authors thank the project partners which provided useful feedbacks and relevant data: Cobra instalaciones y servicios S.A, IDIE Investigacion Desarrollo y Innovacion Energetica SL, SBP sonne gmbh, Fundacion tecnalia research \& innovation, ETRA investigacion y desarrollo SA, CESI-centro elettrotecnico sperimentale italiano 'Giancinto Motta' SPA, Diacheiristis ellinikou diktyou dianomis elektrikis energeias AE, Institute of communication and computer systems, EA Energianalyse AS and the Technical University of Denmark DTU.

\section{REFERENCES}

1. GRIDSOL consortium. (2018). GRIDSOL - A Dynamic Output Manager of Energy (DOME) Research Project. Retrieved August $7^{\text {th }}, 2019$, from: http://www.gridsolproject.eu/

2. Renewables now (2019), "Dubai CSP tender attracts world's lowest bid". Retrieved August $12^{\text {th }}$, 2019, from: https://renewablesnow.com/news/dubai-csp-tender-attracts-worlds-lowest-bid-571170/

3. IRENA (2019), "Renewable power generation costs in 2018". Retrieved August 27 ${ }^{\text {th }}$, 2019, from: https://www.irena.org/-/media/Files/IRENA/Agency/Publication/2019/May/IRENA_Renewable-PowerGenerations-Costs-in-2018.pdf

4. Electricidade de Madeira (2019), "Relatórios e Contas de energia". Retrieved March 12 ${ }^{\text {th }}$, 2019, from: https://www.eem.pt/pt/conteudo/anúncios-e-publicações/publicações/relatórios-e-contas/.

5. HEDNO (2019), "Monthly Reports of RES \& Thermal Units in the non-Interconnected Islands". Retrieved March 12 ${ }^{\text {th }}$, 2019, from: https://www.deddie.gr/en/themata-tou-diaxeiristi-mi-diasundedemenwn-nisiwn/agora$\mathrm{mdn} /$ stoixeia-ekkathariseon-kai-minaion-deltion-mdn/miniaia-deltia-ape-thermikis-paragogis/.

6. Gobierno de Canarias (2019), "Anuario Energético de Canarias". Retrieved March 12 ${ }^{\text {th }}$, 2019, from: http://www.gobiernodecanarias.org/ceic/energia/publicaciones/.

7. Red Electrica de Espana (2019), "ESIOS - Data Download". Retrieved April 5 th $^{\text {th }}$ 2019, from: https://www.esios.ree.es/en/downloads?date type=publicacion\&start date=27-03-2019\&end date=27-03-2019

8. Red Electrica de Espana (2019), "ESIOS Sistema de Informacion del Operador del Sistema". Retrieved April $5^{\text {th }}, 2019$, from: https://www.esios.ree.es/es?locale=es.

9. Gobierno de Canarias (2017), "Documento Preliminar de la Estrategia Energética de Canarias 2015-2025". Retrieved June $26^{\text {th }}$, 2019, from: http://www.gobiernodecanarias.org/ceic/energia/temas/planificacion/EECan25_DocumentoPreliminar junio20 17.pdf.

10. AREAM - Agência Regional da Energia e Ambiente da Região Autónoma da Madeira (2012), "Action plan for sustainable energy 2012-2020 (Plano de accao para a energia sustentavel)". Ilha de Madeira.

11. European Commission (2016), "SA.44666 New RES and CHP support scheme in Greece". JOCE C/83/2017, Retrieved April $\quad 2^{\text {nd }}, \quad$ 2019, from: http://ec.europa.eu/competition/elojade/isef/case details.cfm?proc_code=3_SA_44666.

12. Ministerio de Industria Energía y Turismo (2015), "Real Decreto $738 / 2015$, de 31 de julio, por el que se regula la actividad de producción de energía eléctrica y el procedimiento de despacho en los sistemas eléctricos de los territorios no peninsulares". BOE-A-2015-8646, 2015. Retrieved March 20 ${ }^{\text {th }}$, 2019, from: https://www.boe.es/eli/es/rd/2015/07/31/738.

13. Ministerio de Industria Energía y Turismo (2014), "Real Decreto 413/2014, de 6 de junio, por el que se regula la actividad de producción de energía eléctrica a partir de fuentes de energía renovables, cogeneración y residuos". BOE-A-2014-6123, 2014. Retrieved March 20 https://www.boe.es/eli/es/rd/2014/06/06/413.

14. Ministério da Economia da Inovação e do Desenvolvimento (2011), "Decreto-Lei 5/2011, 2011-01-10". Retrieved July $3^{\text {rd }}, 2019$, from: https://dre.pt/pesquisa/-/search/485634/details/maximized.

15. GRIDSOL consortium (2019), "WP2 - Modelling of Non-dispatchable res and synchronous generation in smart renewable hubs, D2.3-D2.6". Retrieved August 12 $2^{\text {th }}$, 2019, from: http://www.gridsolproject.eu/deliverables/ 
16. Danish Energy Agency (2019), "Technology Data for Generation of Electricity and District Heating”. Retrieved August $27^{\text {th }}$, 2019, from: https://ens.dk/en/our-services/projections-and-models/technology-data/technologydata-generation-electricity-and

17. M. Baldini and C. Perez Hernan Cabrera (2016), "Analysis of regulation and economic incentives of the hybrid CSP HYSOL". Retrieved July $24^{\text {th }}$, 2019, from: https://orbit.dtu.dk/en/publications/analysis-of-regulation-andeconomic-incentives-of-the-hybrid-csp-hysol(5fa0c74e-8451-47fa-a659-7a 8789105bf0).html .

18. E. Fedato et al. (2019), "Feasibility analysis of GRIDSOL technology in Fuerteventura: a case study". Retrieved July 24 $4^{\text {th }}, 2019$, from: https://orbit.dtu.dk/en/publications/feasibility-analysis-of-gridsol-technology-infuerteventura-a-case-study(f42cbbe4-90a7-43a7-a988-0fc40302cf81).html

19. HEDNO (2019), "NII statistics reports". Retrieved April 5 $5^{\text {th }}, 2019$, from: https://www.deddie.gr/en/themata-toudiaxeiristi-mi-diasundedemenwn-nisiwn/agora-mdn/stoixeia-ekkathariseon-kai-minaion-deltion-mdn/stoixeiaekkathariseis-mdn/

20. Entidade reguladora dos servicos energeticos (ERSE) (2019), "Proveitos permitidos das empresas reguladas do sector eléctrico". Retrieved July $8^{\text {th }}$, 2019, from: http://www.erse.pt/pt/electricidade/tarifaseprecos/2019/Documents/Proveitos e Ajustamentos 2019.pdf

21. European Commission, "A European strategic long-term vision for a prosperous, modern, competitive and climate neutral economy". Retrieved August 16 ${ }^{\text {th }}, 2019$, from: https://eur-lex.europa.eu/legalcontent/EN/TXT/?uri=CELEX:52018DC0773

22. GRIDSOL consortium, "WP7 - Impact D7.1-D7.4". Retrieved August 12th 2019, from http://www.gridsolproject.eu/deliverables/

23. R. Brückmann, (2019) "What is the development of WACC for wind power in the 28 EU Member States-and why?". Retrieved June $24^{\text {th }}$, 2019, from: http://www.strommarkttreffen.org/201803 Brueckmann_Development of_WACC_for_wind_in_EU28.pdf.

24. International Monetary Fund (2018), "Inflation Rate". Retrieved June 24 ${ }^{\text {th }}$, 2019, from: https://www.imf.org/external/pubs/ft/weo/2019/01/weodata/weoselgr.aspx

25. Trading Economics (2019), "Corporate Tax Rate". Retrieved June 24 ${ }^{\text {th }}$ 2019, from: https://tradingeconomics.com/country-list/corporate-tax-rate?continent=europe .

26. ZEC (2018), "Canary Island Special Zone". Retrieved June 24 $4^{\text {th }}$, 2019, from: https://canariaszec.com/en/resources/multilingual-brochures/.

27. International Business Centre of Madeira (2019), "Tax Benefits". Retrieved June 24 ${ }^{\text {th }}$, 2019, from: https://www.ibc-madeira.com/en/tax-benefits.html . 